\title{
Mechanism of Antiviral Activity of Nitazoxanide against the Influenza Virus: Effect of Tizoxanide on AdenosineTriphosphate in Influenza-virus Infected Madin Darby Canine Kidney Cells
}

\author{
${ }^{1}$ Rossignol, J.F., ${ }^{2}$ Tijsma, A.S.L., ${ }^{2}$ van Baalen, C.A. \\ ${ }^{1}$ Romark Laboratories L.C., Tampa, Florida $\&{ }^{2}$ Viroclinics Biosciences, Rotterdam, \\ The Netherlands
}

\begin{abstract}
Background

Nitazoxanide (NTZ) is a broad-spectrum antiviral undergoing clinical development for treating influenza and other viral respiratory infections such as those caused by rhinovirus/enterovirus and coronavirus including the emerging SARS-CoV-2.
\end{abstract}

Methods

Nitazoxanide is a mild uncoupler of oxidative phosphorylation, which is modulating the ATP production in cells. ATP is an essential component of viral replication, and we have evaluated the effect of tizoxanide (TIZ), the active circulating metabolite of NTZ, on ATP in Madin-Darby canine kidney (MDCK) cells and in MDCK cells infected with influenza A and B viruses.

Results

TIZ decreased cellular ATP in a dose-dependent manner in MDCK cells and in MDCK cells infected with influenza A and B viruses. Maximum inhibition of ATP in influenza infected or uninfected MDCK cells reached up to $45 \%$ after 6 and 24 hours of exposure to $100 \mu \mathrm{M}$ TIZ. The decrease in cellular ATP did not affect cell viability and was reversible after eliminating TIZ from the culture.

Conclusion

The concentrations of TIZ required to decrease cellular ATP levels were similar to those reported to inhibit replication of influenza A and B viruses in our laboratory. A decrease in ATP triggers activation of AMP-activated protein kinase, which is known to suppress the secretion of pro-inflammatory cytokines. Additional studies are warranted to evaluate the effect of TIZ on mitochondrial function. 


\section{Introduction}

Nitazoxanide (NTZ) is a broad-spectrum antiviral agent undergoing clinical development for treating influenza and other viral respiratory diseases including COVID-19 ${ }^{1-3}$. It is a mild uncoupler of oxidative phosphorylation. ${ }^{4} \quad$ Mechanistic studies have shown that NTZ and its active circulating metabolite, tizoxanide (TIZ), block maturation of the influenza hemagglutinin glycoprotein at the posttranslational stage. ${ }^{5}$ The broad-spectrum antiviral activity of NTZ and the inability to select for resistance suggest a host target, but a specific target has not yet been clearly identified. ${ }^{6}$ In an effort to understand the mechanism of antiviral activity of TIZ better, we evaluated the effect of TIZ on ATP in MDCK cells and in MDCK cells infected with influenza A and B viruses.

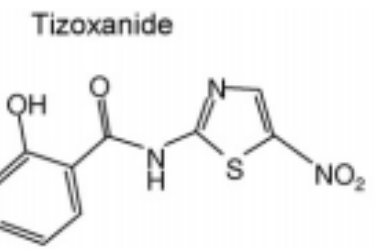

\section{Material and Methods}

\subsection{Material}

\section{Compounds}

TIZ was provided by Romark (Tampa, Florida USA). Working stocks of TIZ dissolved in DMSO were prepared and stored at $-80^{\circ} \mathrm{C}$ until used.

\section{Cell cultures}

Madin-Darby canine kidney (MDCK) cells were passaged in flasks and seeded in 96-well plates. Before inoculation, cells were cultured in MDCK medium and after inoculation in infection medium containing N-tosyl-L-phenylalanyl chloromethyl ketone (TPCK)-treated trypsin $(3 \mu \mathrm{g} / \mathrm{mL} ; \quad$ Sigma, T1426).

\subsection{Methods}

Measurement of ATP. ATP measurements were performed using the CellTiter-Glo Luminescent Cell Viability Assay (Promega, Madison, Wisconsin USA) according to the manufacturer's instructions, with the exception that cell culture medium was aspirated prior to adding $100 \mu \mathrm{L}$ of ATP reagent per well. Opaque walled 96-well plates were used.

Measurement of dehydrogenase activity. Dehydrogenase activity was measured using the Cell Counting Kit-8 (Sigma-Aldrich). Twenty- $\mu$ L WST-8 reagent was added to each well of 96-well plates 
already containing $200 \mu \mathrm{L}$ cell culture medium per well and incubated for $1-2$ hours at $37{ }^{\circ} \mathrm{C}$. After incubation, absorbance was measured at $450 \mathrm{~nm}$.

Experiments in uninfected MDCK cells. Multiple identical plates with MDCK cells were prepared. Cellular ATP levels and dehydrogenase activity were measured after 6 and 24 hours of exposure to various TIZ concentrations (0 to $100 \mu \mathrm{M})$. Nuclei of MDCK cells were stained with DAPI (Life technologies) after treatment with TIZ for 6 or 24 hours. Images were taken using a CTL ImmunoSpot S6 Analyzer and in a representative area of the well, the cell nuclei were quantified using Immunospot software. Using identical replicate plates, the compound was removed; cells were incubated again in fresh cell culture medium (without TIZ) for 24 hours after which cell nuclei were quantified again.

Experiments in influenza virus-infected MDCK cells. Multiple identical 96-well plates with MDCK cells were (mock) infected with two influenza A and two influenza B strains for one hour at low and high MOI. After this period, the inoculum was aspirated and replaced by medium containing various TIZ concentrations $(0,10,30,100 \mu \mathrm{M})$. The cell cultures were incubated for an additional five hours (single cycle infection, high MOI) or 23 hours (multi-cycle infection, low MOI) after which cellular ATP levels were determined. In addition, cells were immunostained for influenza (for influenza A: HB65, EVL; for influenza B: MAB8661, Millipore). Images were taken using a CTL ImmunoSpot S6 Analyzer and the percentage well area covered (WAC) by influenza-positive cells was quantified using Immunospot software. The virus input was checked by back titration.

\section{Results}

\section{Uninfected MDCK cells}

At six hours post-TIZ treatment, a concentration-dependent decrease of cellular ATP levels was observed, starting at $12.5 \mu \mathrm{M}$ TIZ and higher with a maximum ATP decrease of $45 \%$ at $100 \mu \mathrm{M}$ TIZ. After 24 hours of treatment with TIZ, the maximum reduction was similar ( $44 \%$ at $100 \mu \mathrm{M})$; however, reduction of ATP was observed at lower concentrations of TIZ $(6.25 \mu \mathrm{M})$ as compared to 6 hours.

To assess if TIZ affected cell viability, we also measured dehydrogenase activity because it is often used as an ATP-independent measure for cell viability. After 6 hours of exposure to TIZ, dehydrogenase activity was at the level of untreated control cells, although at high concentrations of TIZ $(\geq 50 \mu \mathrm{M}$ ), the activity increased somewhat (Fig. 1A). After 24 hours of TIZ treatment, the dehydrogenase activity decreased at higher ( $\geq 50 \mu \mathrm{M})$ TIZ concentrations (Fig. 1B).

To evaluate whether the effect of TIZ on ATP is transient or enduring, MDCK cells were treated with various concentrations of TIZ for 24 hours. After this period, the cells were washed once with PBS 
to remove TIZ, and fresh cell culture medium (not containing TIZ) was added to the cells. After a subsequent incubation period of 1, 6, and 24 hours, the cellular ATP levels were determined (Fig. 1C). In this experiment, cellular ATP levels recovered with increasing incubation time. At concentrations of $12.5 \mu \mathrm{M}$ and lower, ATP levels recovered to the level of untreated control cells. However, at higher concentrations $(\geq 25 \mu \mathrm{M})$, full recovery did not occur within the timeframe of 24 hours.

To exclude the possibility that reduced ATP levels and dehydrogenase activity are due to a reduced number of cells in the wells (due to detachment, apoptosis and necrosis for instance), MDCK cells nuclei were stained with DAPI and quantified once TIZ treatment was completed (Fig. 1D). The number of cells did not significantly decrease after treatment with $100 \mu \mathrm{M}$ TIZ for 6 or 24 hours. Moreover, when cells were incubated with $100 \mu \mathrm{M}$ TIZ, after which the compound was removed and incubated again in fresh cell culture medium for 24 hours, the number of nuclei increased, most likely due to cell proliferation.

6 hours
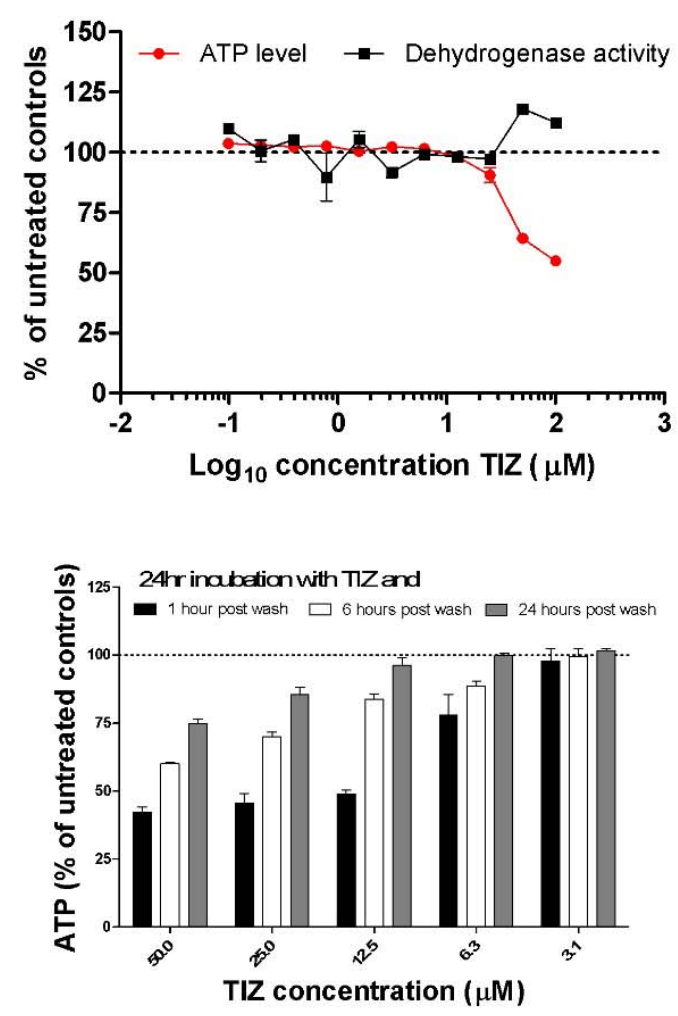

24 hours
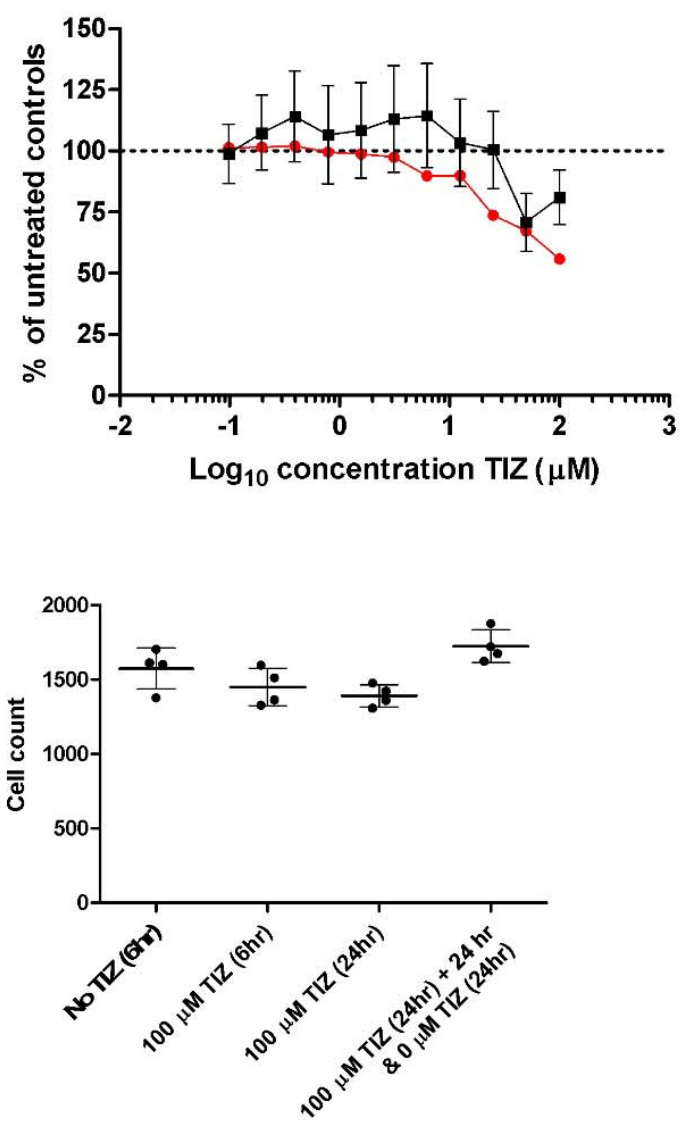

Fig. 1. Effect of TIZ on ATP levels, dehydrogenase activity and cell count in uninfected MDCK cells. Effect of TIZ on ATP levels and dehydrogenase activity after 6 (A) and 24 (B) hours of incubation with the compound. Effect 
of TIZ on ATP levels were also assessed after 24 hours of incubation with TIZ after which the medium was refreshed (not containing TIZ) and subsequent incubation for 1, 6 and 24 hours (C). The effect of TIZ on the number of attached cells was determined by counting DAPI stained cell nuclei after various incubation times with $100 \mu \mathrm{M}$ of TIZ (D). Each datapoint is the mean \pm SD of 4 replicates.

\section{Influenza virus-infected MDCK cells}

We then measured ATP levels in MDCK cells infected with two influenza A virus strains and two influenza B virus strains using both single cycle (6 hours, multiplicity of infection (MOI) > 1) and multicycle (24 hours, MOI $\leq 0.01$ ) infection. For both single- and multicycle infection (Fig. $2 \mathrm{~A}$ and 2 B), TIZ reduced ATP in influenza-infected cells in a concentration-dependent manner, similarly to its effect in uninfected cells. For the single cycle infection (Fig 2C), back titration showed that the MOI used in the assay varied between 1.2 and 20.4. Virus replication was assessed by influenza-specific immunostaining of the cell monolayer. The well area covered by the immunostaining was calculated and is a measure of virus replication. The maximum reduction of well area covered by influenza virus spots was 3.7-fold when cell cultures were treated with $100 \mu \mathrm{M}$ TIZ. At 30 and $10 \mu \mathrm{M}$, the reduction was at most 1.5 -fold.

For the multicycle infection (Fig 2D), back titration results showed that the MOI used in the assay varied between 0.004 and 0.01 . Full inhibition of virus replication was observed for B/Phuket when incubated with $100 \mu \mathrm{M}$ TIZ. The negative well area covered (WAC) for this culture condition (-0.2) is because the background WAC was slightly higher than the specific WAC of this culture condition; hence, no fold reduction could be calculated, which was denoted with " $\infty$ ". For the other viruses, treated with $100 \mu \mathrm{M}$ TIZ, the fold reduction varied between 5.2 and 29.8-fold. At 30 and $10 \mu \mathrm{M}$ TIZ, the reduction was at most 5.2-fold. It has to be noted that the fold reduction for A/Michigan at 100 and $30 \mu \mathrm{M} \mathrm{TIZ}$ is likely to be larger than could be calculated since the wells not treated with TIZ were completely positive for influenza NP, meaning that uninhibited virus propagation was capped by the well area.

Fig. 2. TIZ decreases ATP in influenza virus-infected MDCK cells during single cycle infection (A) and multi-cycle infection (B). Data depicted in the graph are the means of at least 4 determinations, error bars represent the SD. Fold reduction in well area covered (WAC) by influenza virus spots (\%) in TIZ treated cultures compared to untreated cultures in single cycle (C) and multicycle infection (D). Percentages shown are the means of at least 4 replicates. Background \%WAC (uninfected cell controls) is subtracted to calculate the specific \%WAC of each culture condition, shown here.

A

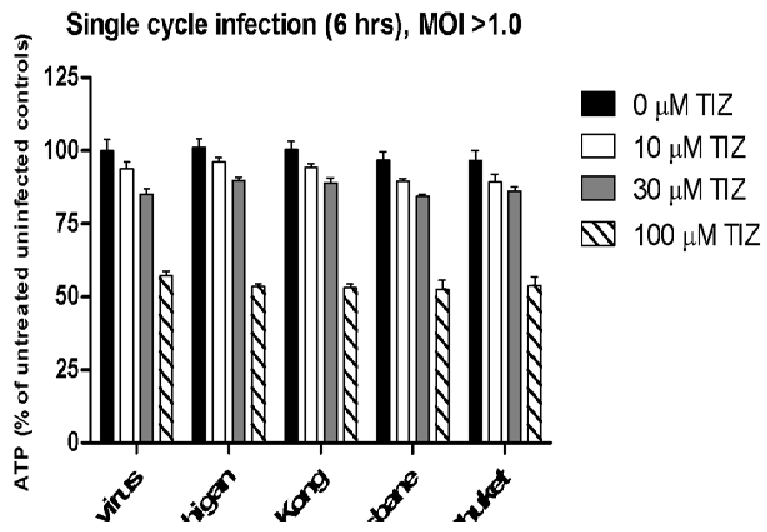

B

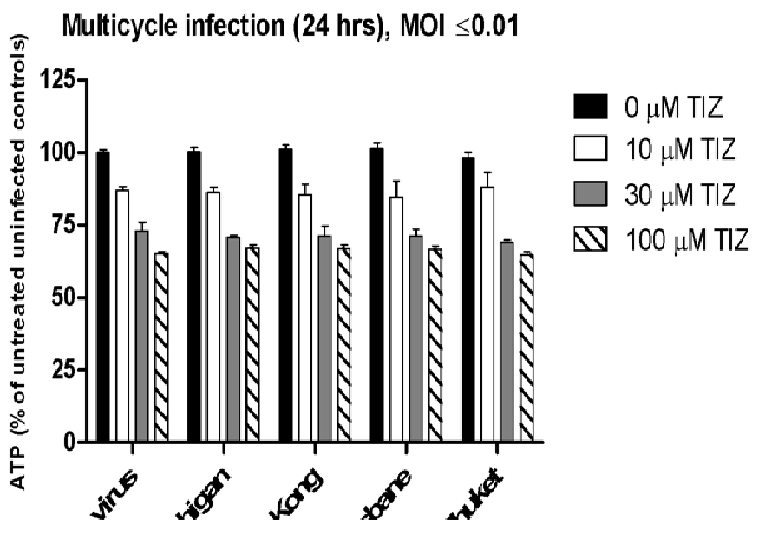




\begin{tabular}{|c|c|c|c|c|c|c|c|c|c|c|}
\hline \multirow[b]{2}{*}{$\begin{array}{l}\text { Single cycle } \\
\text { infection (6 } \\
\text { hrs), MOI > } \\
1.0\end{array}$} & \multirow[b]{2}{*}{ MOI } & \multicolumn{2}{|c|}{$\begin{array}{l}\text { Well area } \\
\text { covered by } \\
\text { influenza } \\
\text { virus spots } \\
(\%)\end{array}$} & \multirow[t]{2}{*}{$\begin{array}{l}\text { Fold } \\
\text { Reduction }\end{array}$} & \multicolumn{2}{|c|}{$\begin{array}{l}\text { Well area } \\
\text { covered by } \\
\text { influenza } \\
\text { virus spots } \\
(\%)\end{array}$} & \multirow[t]{2}{*}{$\begin{array}{l}\text { Fold } \\
\text { Reduction }\end{array}$} & \multicolumn{2}{|c|}{$\begin{array}{l}\text { Well area } \\
\text { covered by } \\
\text { influenza } \\
\text { virus spots } \\
(\%)\end{array}$} & \multirow[t]{2}{*}{$\begin{array}{l}\text { Fold } \\
\text { Reduction }\end{array}$} \\
\hline & & $\begin{array}{l}0 \\
\mu \mathrm{M} \\
\mathrm{TlZ}\end{array}$ & $\begin{array}{l}10 \\
\mu \mathrm{M} \\
\mathrm{TlZ}\end{array}$ & & $\begin{array}{l}0 \\
\mu \mathrm{M} \\
\mathrm{TlZ}\end{array}$ & $\begin{array}{l}30 \\
\mu \mathrm{M} \\
\mathrm{TlZ}\end{array}$ & & $\begin{array}{l}0 \\
\mu \mathrm{M} \\
\mathrm{TlZ}\end{array}$ & $\begin{array}{l}100 \\
\mu \mathrm{M} \\
\mathrm{TlZ}\end{array}$ & \\
\hline A/Michigan & 6.2 & 13.6 & 18.9 & 0.7 & 18.1 & 17.3 & 1 & 15.1 & 4.7 & 3.2 \\
\hline $\begin{array}{l}\text { A/Hong } \\
\text { Kong }\end{array}$ & 1.2 & 1.6 & 1.7 & 0.9 & 4.1 & 2.8 & 1.5 & 3 & 1.2 & 2.4 \\
\hline $\mathrm{B} /$ Brisbane & 9.1 & 6.2 & 8.7 & 0.7 & 10.1 & 8.9 & 1.1 & 10.6 & 3.5 & 3 \\
\hline B/Phuket & 20.4 & 9.0 & 11.3 & 0.8 & 8.7 & 9.6 & 0.9 & 14.2 & 3.8 & 3.7 \\
\hline
\end{tabular}

D

\begin{tabular}{|c|c|c|c|c|c|c|c|c|c|c|}
\hline \multirow[b]{2}{*}{$\begin{array}{l}\text { Single } \\
\text { cycle } \\
\text { infection (6 } \\
\text { hrs), MOI > } \\
1.0\end{array}$} & \multirow[b]{2}{*}{ MOI } & \multicolumn{2}{|c|}{$\begin{array}{l}\text { Well area covered by } \\
\text { influenza virus spots } \\
(\%)\end{array}$} & \multirow[b]{2}{*}{$\begin{array}{l}\text { Fold } \\
\text { Reduction }\end{array}$} & \multicolumn{2}{|c|}{$\begin{array}{l}\text { Well area covered by } \\
\text { influenza virus spots } \\
(\%)\end{array}$} & \multirow[b]{2}{*}{$\begin{array}{l}\text { Fold } \\
\text { Reduction }\end{array}$} & \multicolumn{2}{|c|}{$\begin{array}{l}\text { Well area covered by } \\
\text { influenza virus spots } \\
(\%)\end{array}$} & \multirow[b]{2}{*}{$\begin{array}{l}\text { Fold } \\
\text { Reduction }\end{array}$} \\
\hline & & $0 \mu \mathrm{M} \mathrm{TlZ}$ & $\begin{array}{l}10 \mu \mathrm{M} \\
\mathrm{TlZ}\end{array}$ & & $0 \mu \mathrm{M} \mathrm{TlZ}$ & $\begin{array}{l}30 \mu \mathrm{M} \\
\mathrm{TlZ}\end{array}$ & & $0 \mu \mathrm{M} \mathrm{TlZ}$ & $\begin{array}{l}100 \mu \mathrm{M} \\
\mathrm{TlZ}\end{array}$ & \\
\hline A/Michigan & 0.01 & 25.0 & 19.5 & 1.3 & 23 & 14.9 & 1.5 & 23 & 4.4 & 5.2 \\
\hline $\begin{array}{l}\text { A/Hong } \\
\text { Kong }\end{array}$ & 0.01 & 13 & 12.3 & 1.1 & 13.6 & 4 & 3.4 & 20.8 & 0.7 & 29.8 \\
\hline $\mathrm{B} /$ Brisbane & 0.004 & 3.5 & 1.5 & 2.4 & 3 & 0.8 & 3.7 & 4.6 & 0.3 & 19.6 \\
\hline B/Phuket & 0.01 & 7.8 & 5.1 & 1.5 & 7.4 & 1.4 & 5.2 & 9.9 & -0.2 & $\infty$ \\
\hline
\end{tabular}




\section{Discussion}

These data show that TIZ decreases cellular ATP in a dose-dependent manner in MDCK cells and in MDCK cells infected with influenza A and B viruses. Maximum inhibition of ATP in influenza infected or uninfected MDCK cells reached up to $45 \%$ after 6 and 24 hours of exposure to $100 \mu \mathrm{M}$ TIZ. The decrease in cellular ATP did not affect cell viability and was reversible after removing TIZ from the culture. The concentrations of TIZ required to decrease cellular ATP levels were similar to those reported to inhibit replication of influenza A and B viruses in our laboratory.

Studies of a number of different viruses have shown that viral replication is ATP-dependent. Braakman et al. first described the role of ATP in the formation of disulphide bonds during the maturation and the protein folding of the influenza hemagglutinin in the endoplasmic reticulum in $1991 .^{7}$ The following year, 1992, Braakman et al further studied the effects of ATP on viral replications. ${ }^{8}$ Their results were consistent with our results on the effect of NTZ on the maturation of influenza glycoprotein in the endoplasmic reticulum. ${ }^{5}$ It was later shown that ATP is regulating the assembly and the transport of vesicular stomatitis virus $G$ protein trimers ${ }^{9}$ and that an increased ATP generation in the host cells was required for an efficient vaccinia virus production. ${ }^{10}$ Finally, Mirazimi \& Svensson showed that ATP was an essential component for correct folding and disulphide bond formation in rotavirus. ${ }^{11}$

NTZ and TIZ are modulators of mitochondrial activity by uncoupling oxidative phosphorylation. ${ }^{4}$ NTZ targets the maturation of key viral proteins in the endoplasmic reticulum, hemagglutinin (influenza), F-protein, (RSV \& parainfluenza) and N-protein (coronavirus). ${ }^{5,12-13}$ Effectively, we have been able to show that NTZ blocks the proper folding of proteins of two paramyxoviridae, the respiratory syncytial virus (RSV) or the Sendai virus $(\mathrm{SeV})$ in blocking the effect of disulfide isomerase ERp57. ${ }^{12}$

An indirect effect of ATP inhibition by targeting mitochondrial activity is triggering the phosphorylation of the AMP-activated protein kinase (AMPK) suppressing the secretion of proinflammatory cytokines ${ }^{14-16}$ while in a few cases such as metformin the activation of AMPK is not affected by the ATP level in the cells. ${ }^{17}$

Anti-cytokines activity of TIZ was demonstrated in cell bioassays against seven proinflammatory cytokines, TNF-alpha, Il-2, IL-4, IL-5, IL-6, IL-8 and IL-10 with $\mathrm{IC}_{50}$ s ranging from 0.67 to $2.65 \mu \mathrm{g} / \mathrm{mL}$. Hong et all have also investigated the effect of NTZ on pro-inflammatory cytokines. ${ }^{18}$ The drug suppresses lipopolysaccharide (LPS)-induced production of IL-6 from RAW 264.7 cells and mouse peritoneal macrophages with $50 \%$ inhibitory concentrations $\left(\mathrm{IC}_{50} \mathrm{~s}\right)$ of $1.54 \mu \mathrm{M}$ and $0.17 \mu \mathrm{M}$, respectively. NTZ also inhibited the LPS-induced expression of IL-6 mRNA in RAW 264.7 cells. In vivo the drug was orally administered at a dose of $100 \mathrm{mg} / \mathrm{kg}$ to mice 2 hours before a $1 \mathrm{~mL}$ intraperitoneal injection of $4 \%$ thioglycollate (TG). Six hours after TG injection, plasma IL-6 levels were markedly 
lower (by 90\%) than the levels in vehicle-treated mice. These data suggest that nitazoxanide could be a promising drug against various diseases associated with overproduction of IL- $6{ }^{18}$

\section{Conclusion}

The antiviral mechanism of action of NTZ/TIZ is related to the energy metabolism process in cells. The modulating effect of the drug on mitochondria results in a modest decrease of the ATP concentration in influenza infected and in non-infected cells. This reduction does not affect the viability of the cells but prevents the maturation of viral proteins in the endoplasmic reticulum. In addition, a decrease of ATP is activating the AMP-activated protein kinase (AMPK) responsible for blocking the secretion of several pro-inflammatory cytokines. In effect, cell-based assays showed that concentrations of tizoxanide prevent the secretion of TNF-alpha, Il-1, IL-2, IL-3, IL-5, IL-8, IL-10 with IC $_{50}$ from 0.67 to $2.65 \mu \mathrm{g} / \mathrm{mL}$. Effects against IL-6 have also been reported in cell assays and in vivo. However, this anticytokine activity may not be clinically significant and needs to be proven in patients infected with a viral illness.

\section{Acknowledgment}

Jean-François Rossignol is the inventor and the developer of Nitazoxanide. He holds several patents on the drug and its applications. He also is the co-founder of Romark Laboratories, L.C. a stockholder and an employee of the company. Carel van Baalen and Aloys Tijsma are employees of Viroclinics Biosciences B.V. in Rotterdam, The Netherlands.

\section{Authors Contribution}

Jean-François Rossignol designed the aforementioned experiment, and he is the primary author of this publication. Carl van Baalen and Aloys Tijsma performed the experimental research under a contract with Romark Laboratories L.C.

\section{Disclosure Statement}

Authors do not have conflict of interest. 


\section{References}

1. Rossignol JF. Nitazoxanide: A first-in-class broad-spectrum antiviral agent. Antiviral Res 2014; 110:94-103.

2. Haffizulla, J., Hartman, A., Hoppers, M., Resnick, H., Samudrala, S., Ginocchio, C., Bardin, M., Rossignol,

Randomized, Double-Blind, Placebo Controlled Clinical Trial of Nitazoxanide in Adults and Adolescents with Acute Uncomplicated Influenza. Lancet Infectious Diseases. 2014; 14:609-618.

3. Wang, M., Cao, R., Zhang, L., Yang, X., Liu, J., Xu, M. Shi, Z. Hu, Z., Zhong, W. \& Xiao, G. Remdesivir and Chloroquine effectively inhibit the recently emerged novel coronavirus (2019nCoV) in vitro. Cell Research (2020) 0:1-3; https://doi.org/10.1038/s41422-020- 0282-0.

4. Senkowski W, Zhang X, Olofsson MH, Isacson R, Höglund U, Gustafsson M, Nygren P, Linder S, Larsson R, Fryknäs M. Three-dimensional cell culture-based screening identifies the anthelmintic drug nitazoxanide as a candidate for treatment of colorectal cancer. Mol Cancer Ther 2015;14:1504-16.

5. Rossignol JF, La Frazia S, Chiappa L, Ciucci A, Santoro MG. Thiazolides, a new class of antiinfluenza molecules targeting viral hemagglutinin at post-translational level. J Biol Chem 2009; 284:29798-808.

6. Tilmanis D, van Baalen C, Oh DY, Rossignol JF Hurt AC The susceptibility of recently circulating human influenza viruses to nitazoxanide using a focus reduction assay Antiviral Research 2017;147:142- 148.

7. Braakman I, Hoover-Litty H, Wagner KR, Helenius A. Folding of influenza hemagglutinin in the endoplasmic reticulum. J Cell Biol 1991; 114:401-411.

8. Braakman I., Helenius J, Helenius A. Role of ATP and disulphide bonds during protein folding in the endoplasmic reticulum. Nature 1992; 356:260-262.

9. Doms RW, Keller DS, Helenius A, Balch WE. Role of adenosine triphosphate in regulating the assembly and transport of vesicular stomatitis virus G protein trimers. J Cell Biol 1987; 105:10957-1969.

10. Chang CW, Li HC, Hsu CF, Chang CY, Lo SY. Increased ATP generation in the host cell is required for efficient vaccinia virus production. J Biomed Sci 2009; 16:80.

11. Mirazimi A, Svensson L. ATP is required for correct folding and disulfide bond formation rotavirus VP7. J Virol 2000; 74:8048-52. 
12. Piacentini, S., La Frazia, S.L., Riccio, A. Pedersen, J.Z., Topai, A., Nicolotti, O., Rossignol, J.F. \& Santoro, M.G. Antiviral thiazolides trigger paramyxovirus fusion protein misfolding by targeting the endoplasmic reticulum disulfide isomerase ERp57. Scientific Reports 2018; 8: 10425 .

13. Cao J, Forest C, Zhang X A screen of the NIH clinical collection small molecule library identifies potential anti-coronavirus drugs Antiviral Res, 2015; 114: 1-10.

14. Lee JH, Zhang Y, Zhao Z, Ye X, Zhang X, Wang H, Ye J. Intracellular ATP in balance of proinflammatory and anti-inflammatory cytokines in adipose tissue with and without tissue expansion. Int J Obes (Lond) 2017; 41:645-651.

15. Sag D, Carling D, Stout RD, Suttles J. AMP-activated protein kinase promotes macrophage polarization to an anti-inflammatory functional phenotype. J Immunol 2008; 181(12):86338641.

16. Wang W, Yang X, de Silanes IL, Carling D, Gorospe M. Increased AMP:ATP ratio and AMPactivated protein kinase activity during cellular senescence linked to reduced HuR function. $J$ Biol Chem 2003; 278:27016-27023.

17. Hawley, S.A., Gadalla, A.E., Olsen, G.S. \& Hardie, D.G. The Antidiabetic Drug Metformin activates the AMP-Activated Protein Kinase Cascade via Adenine Nucleotide-Independent Mechanism. Diabetes 2002; 51:2420-2425.

18. Hong SK, Kim HJ, Song CS, Choi IS, Lee JB, Park SY Nitazoxanide suppresses IL6 production in LPS- stimulated mouse macrophages and TG-injected mice Int Immunopharmacol, 2012; 13: 23-27. 
bioRxiv preprint doi: https://doi.org/10.1101/2021.07.30.454324; this version posted August 3, 2021. The copyright holder for this preprint (which was not certified by peer review) is the author/funder, who has granted bioRxiv a license to display the preprint in perpetuity. It is made available under aCC-BY-NC-ND 4.0 International license. 